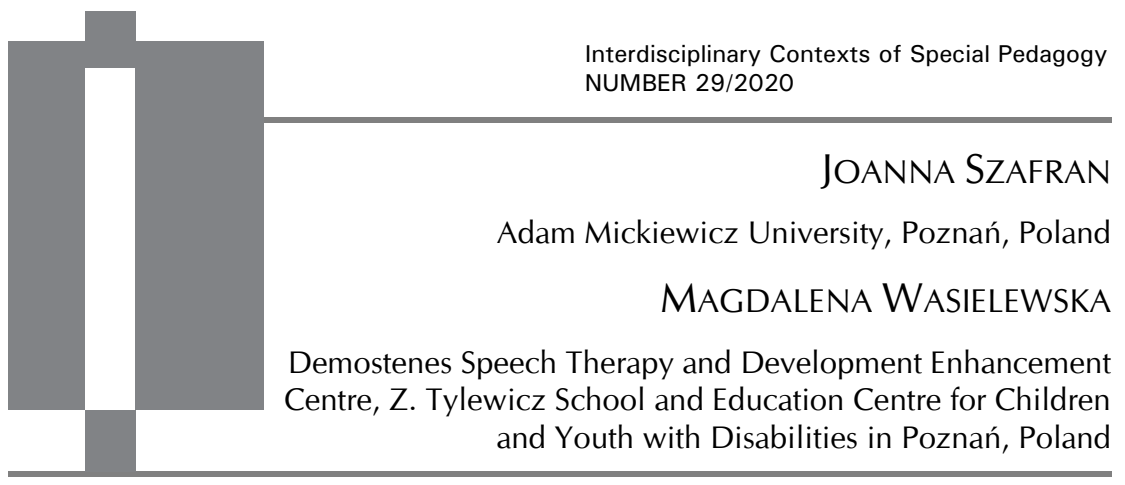

\title{
Tailored Success: Disability and the Possibility of Being Successful
}

\begin{abstract}
Joanna Szafran, Magdalena Wasielewska, Tailored Success: Disability and the Possibility of Being Successful. Interdisciplinary Contexts of Special Pedagogy, no. 29, Poznań 2020. Pp. 237-245. Adam Mickiewicz University Press. ISSN 2300-391X. e-ISSN 2658-283X. DOI: https://doi.org/10.14746/ikps.2020.29.11

The article addresses the issue of success in the context of people with disabilities. Attention was paid to the specific nature of the concept; starting with the definition, attempts were made to point out that success, being a certain "objective" construct, has a definitely individual character and should be considered as such. This individual dimension designates not only the interpretative framework determining its achievement, but also draws attention to the fact that success may have many faces. There is a need for achievement in every person, a completed challenge gives a sense of happiness, and this, according to many, is the real measure of success.
\end{abstract}

KEY WORDS: disability, successful, education

The road to success is always under construction. Lily Tomkin 
The modern world is strongly success-oriented. However, a question emerges: what is success? The dictionary defines it as accomplishment of an aim or purpose, good outcome of an undertaking. 1 Adopting such perspective forces us to go beyond the narrow understanding that is characteristic for economic sciences, but also for the common comprehension where success is identified with a high professional position, accumulated wealth, fame, etc. The dictionary definition shows that the measure of success is not the "objective" social assessment, which is the result of comparison with others, but it may be an inner conviction that something has been accomplished. When interpreting the concept of success, scientific milieus, coaches and therapists often identify it with the process of self-fulfilment. T. Tomaszewski attracts attention to the fact that such approach is close to humanistic psychology and claims: "(...) humanistic psychologists put main emphasis not on disclosing and satisfying man's inner (...) drives, but on revealing and activating his inner potential, in other words his self-realisation". ${ }^{2}$ Such need of self-fulfilment is an important factor activating the individual's potential and triggering action, in the consequence of which success becomes feasible, offering a feeling of satisfaction. According to Witkowski "to accomplish success is to obviously be lucky". ${ }^{3}$ Psychologists, whilst relating success to happiness, attitude, selfrecognition and self-fulfilment, draw attention to the fact that it may be conditioned by the individual's potential related to his/ her degree of interest in a given area, which is the planned territory for accomplishing success. ${ }^{4} \mathrm{~K}$. Gołąb notes that success is related to an

1 Słownik jezzyka polskiego, ed. E. Sobol, Wydawnictwo Naukowe PWN, Warszawa 2005, p. 973.

${ }^{2}$ T. Tomaszewski, Główne idee wspótczesnej psychologii, Wydawnictwo Akademickie Żak, Warszawa 1998, p. 87.

3 S. Witkowski, Psychologia sukcesu, Wydawnictwo Naukowe PWN, Warszawa 1994, p. 16.

${ }^{4}$ Cf. C. Dweck, Nowa psychologia sukcesu, Muza S.A., Warsaw 2013; E. Nęcka, Inteligencja. Geneza - Struktura - Funkcje, Gdańskie Wydawnictwo Psychologiczne, Gdańsk 2002, p. 209. 
action that accomplishes the highest possible level for an individual, oriented at satisfying desires and fulfilling dreams pertaining to various areas of life, taking the balance among them into account. ${ }^{5}$ The author draws attention to the necessity of planning activities; therefore, success is an intended state referring to the accomplishment of the pre-set tasks/ goals within a specific time. Such approach is also characteristic for the recently fashionable coaching approach. However, it must be emphasised that experiencing success is a highly individualised state, as anybody may relate it to situations, emotions or values important for them. Therefore, it may be assumed that in every case success is going to be related to the feeling of individual fulfilment, and not only its social determinants (above-average accomplishments in a certain area - professional, material, etc.). In this perspective, success ceases to be unequivocal. $\mathrm{S}$. Lebowitz, referring to the definitions of success given by influential people, who are definitely seen as successful in business, indicates that it not only has different faces, but may also be used in diverse ways. For one of the wealthiest men in the world, Bill Gates, success is related to the possibility of influencing the world. He claims that: "It would be nice to feel that you made a difference for the world - you have invented something, you brought up children or helped people in need". ${ }^{6}$ Billionaire R. Branson relates success to the feeling of happiness. In turn, in the opinion of the founder of Huffington Post, A. Huffington 7 , success comprises three factors. The first is power, the second is money and the last consists of wealth, wisdom, admiration and giving. ${ }^{8}$

${ }^{5}$ K. Gołąb, 10 złotych zasad sukcesu, https://posukcesnaszpilkach.pl/2014/10zlotych-zasad-sukcesu/ [10.10.2019].

6 S. Lebowitz, 12 wpływowych osób dzieli się swoimi zaskakującymi definicjami sukcesu, https://businessinsider.com.pl/rozwoj-osobisty/rownowaga/czym-jest-sukcesdefinicje-min-gatesa-bransona-obamy/xr37bcy [10.10.2019].

7 D. Schawbel, Arianna Huffington: Why Entrepreneurs Should Embrace The Third Metric, https://www.forbes.com/sites/danschawbel/2014/03/25/arianna-huffing ton/\#3a102df11aa4 [10.10.2019].

${ }^{8}$ Ibidem. 
Attempts were made to indicate that success is an ambiguous and diverse concept, even though associated most frequently with a high social and economic status and accomplishments, which may entail liability much broader than the borders of one's home; it is also significantly related to the individual feeling of happiness, satisfaction, realisation of own potential and thus self-fulfilment of an individual.

From the perspective of institutions responsible for the educational process of fully able and disabled children and youth, it seems important to quote the definition referenced at the beginning, where success is defined as the positive outcome of undertaken activities.

Ch. Buchner indicates that the most important in accomplishment of success by a child is the feeling of making progress and joy derived from it, readiness to put significant effort into action, steadfast striving for the designated purpose, but primarily accomplishment of results that are adequate to one's potential and talents. ${ }^{9}$ A similar approach is taken by the authors of this text, who understand the tailored success from the title in this manner.

As emphasised by A. Karpinska, introduction of pedagogical factors related to the individual approach and atmosphere fostering development is of fundamental importance in education. The author writes: "Civilisation transformations and educational tendencies resulting from them are related, among others, to a change of the general philosophy of education and formation of a model of studentfriendly education, focused on getting to know and developing the strong sides of the child's personality, which allows the student to accomplish educational successes. At the same time, success does not only refer to the mastering of knowledge and skills offered by the school curriculum, but it is primarily about accomplishments in the area of development of personality of children and youth within the scope of all areas specified in the goals of education" ${ }^{10}$

${ }^{9}$ C. Buchner, Sukces w szkole jest możliwy, Jedność, Warszawa 2004, pp. 13-14.

10 A. Karpińska, W poszukiwaniu źródet edukacyjnego sukcesu. Oferta edukacyjna dla wszystkich, [in:] Edukacja "głębszego poziomu" w dialogu i perspektywie, ed. A. Karpińska, Trans Humana Wydawnictwo Uniwersyteckie, Białystok 2005, p. 11. 
Limiting the understanding of success of a disabled person to the level of knowledge and skills mastered by him/ her may cause disappointment and in consequence lead to withdrawal from activity, if the expectations are too high or impossible to fulfil. No possibility to observe own progress is a demotivating factor. The situation is similar in case of overly protective stance of the environment. Lack of challenges or relieving of daily efforts makes the disabled children convinced about their impotence, which may also lead to the withdrawal from activities and relinquishment of attempts intended to overcome own limitations and realisation of own potential. Such approach not only narrows down the field for success, but also makes it practically unattainable. A responsibly conducted educational process, accompanying and supporting children, teachers and carers should foster conditions making the individual success not only desired, but also feasible. Thus, accomplishment by persons with disabilities of success on their own level depends both on the internal motivation and possibilities, but also the external stimulators. Frequently, these areas condition each other. For example, passion excites the individual to incessant performance of activities which are most frequently supported by friends, teachers and the family. In striving to accomplish the goal, competitors and the desire to compete also play an important role. Success is often perceived as an exceptional accomplishment that has to be noticed. Competition guarantees at least one observer of our efforts; such point of reference reinforces the desire to accomplish the goal and provides an extra incentive. Therefore, the environment may both stimulate the activities oriented at success and hinder or even limit them. Lack of faith in the individual's potential (frequent in case of persons with disabilities) may give rise to a conviction that taking any action is devoid of sense, as there is a significant probability of failure. Stereotypical perception of needs and potential of people with disabilities or transposition of own fears of the family and/ or teachers on the disabled student entails that success is perceived almost exclusively as accomplishment of a specific action and not as 
a process intended to reaching a more comprehensive, holistic development of an individual.

On the other hand, too many rewards may also be a factor discouraging from work. An individual, accustomed to regular rewards and devoid of positive reinforcement, may withdraw from action. The case is similar in the application of attention as a valuating and activating factor, the cessation of which leads to expiry of engagement needed to accomplish the goal. Therefore, in case of too many rewards, the level of motivation drops and thus the probability of accomplishing success is also reduced.

However, as noted by W. Rybak, due to the fact that success is a subjective value, "the potential, even though greatly diversified, is hidden in every person, irrespective of the type of dysfunction". ${ }^{11}$ Therefore, disability is not an obstacle on the road to success. It is rather the excessive expectations or lack of faith in success, too much protection or replacement of incentives with rewards that can make the success unattainable.

In the work with people with disabilities, attention is drawn to the fact that many of them have a higher level of determination and desire to overcome own limitations. The appearing obstacles do not lead to withdrawal from an activity. External support and positive approach to own potential supports activities aimed at accomplishing a specific goal, success reinforces the feeling of self-esteem which, in consequence, reinforces a conviction that success is possible. W. Rybak notes that "every person with a specific dysfunction has individual talents and deficiencies, own rate and rhythm of development"12; such perspective requires understanding of these

11 W. Rybak, Sukces edukacyjny osób niepetnosprawnych w kontekście warunków uprawiania turyzmu na terenie Bieszczadzkiego Parku Narodowego, https://www.repo zytorium.uni.wroc.pl/Content/79784/7.6_Wojciech_Rybak_Sukces_edukacyjny_osob _niepelnosprawnych_w_kontekscie_warunkow_uprawiania_turyzmu_na_terenie_ Bieszczadzkiego_Parku_Narodowego.pdf [15.02.2020].

12 W. Rybak, Sukces edukacyjny osób niepetnosprawnych w kontekście warunków uprawiania turyzmu na terenie Bieszczadzkiego Parku Narodowego, https:/ / www.repozy 
dependences by the environment, acceptance and taking supportive measures.

We are living in a society where knowledge and human awareness of disabilities should be high, yet there are still people among parents and carers of children with disabilities who solidify their feeling of inferiority, thus obstructing their road to success. Meanwhile, reality shows that people with disabilities can be successful in many fields.

For example, pupils from the Z. Tylewicz School and Education Centre for Children and Youth with Disabilities in Poznan won the Champion of Poland title in wheelchair basketball five times; the team also won the Vice Champion title three times and scored the Cup of Poland five times. In 1996, six contestants from the Student Sport Club became members of the national team, which won the $6^{\text {th }}$ place at the Junior World Championship in Canada. In 1997, the team took part in the European Championship in Slovenia, as well as in the first Junior World Championship in Toronto. In 1999, they also participated in another European Championship, which this time was held in Portugal. In the 2007/2008, the disabled basketball players took part in the World Championship in Rio de Janeiro. ${ }^{13}$ The billiards group had similarly impressive accomplishments. Successes of the Centre's pupils are not only related to sports. Participating in the robotics class, they successfully accepted scientific and practical challenges. In 2008, the $5^{\text {th }}$ Robot Festival was held at the Poznan University of Technology and the CybAirBot Robot Sumo Contest. The pupils took part in the "Most Interesting Amateur Robot Structures" and won the first place.

torium.uni.wroc.pl/Content/79784/7.6_Wojciech_Rybak_Sukces_edukacyjny_osob _niepelnosprawnych_w_kontekscie_warunkow_uprawiania_turyzmu_na_terenie_ Bieszczadzkiego_Parku_Narodowego.pdf [15.02.2020], p. 253.

13 Uczniowski Klub Sportowy, http://www.sosw.poznan.pl/ [1.08.2017]; Wasielewska M., Karpińska A., Hurysz M. Krótka historia Specjalnego Ośrodka Szkolno-Wychowawczego dla Dzieci i Młodzieży Niepełnosprawnej im. Zbigniewa Tylewicza w Poznaniu, CLiWR Demostenes, Poznań 2019. 
The above-listed sports and educational success are not separate, individual cases referring to students of one centre; such examples can be multiplied. However, it is not about triumph measured with the colour of medals or the position on a dais, but about success aligned with the potential, predisposition, resources and needs. What for some may be an ordinary and automatic activity, will be a great joy and a reason for pride at the cost of great effort. Therefore, success may be writing a sentence with rounded letters in case of individuals who suffer from excessive muscle tension, learning a poem by heart in case of compromised cognitive ability, fastening a button or tying the shoelaces in case of limited sight and movement coordination, etc.

There are many possibilities of self-fulfilment that offer a feeling of sense and accomplishment in life. There are various faces of success, just like our potentials and desires vary. Everybody has a right to be happy; irrespective of own limitations, we are pre-destined to accomplish minor victories on a daily basis and, overcoming difficulties, to accomplish successes at multiple fields of our human existence. Here, persons with disabilities are no exception. However, it has to be acknowledged with honesty that in many cases, their road to success is much more curvy and bumpy. Without doubt, self-acceptance supported by realistic self-assessment helps on the path to realising own intentions, yet the understanding and support of the environment are also very important. Overcoming our own limitations and prejudice is a challenge for all of us, both fully-able and disabled people. ${ }^{14}$ This calls for going beyond the traditional mental schemes pertaining to success and disability; in such case, success in an enterprise will become much more available. However, in order to make success possible, it should be tailored and form an effect of fulfilment of our needs and possibilities, overcoming of challenges; otherwise, it will either go unnoticed or we will be doomed to constant bitterness of failure.

${ }^{14}$ Cf.: J. Kossewska, Społeczeństwo wobec osób niepetnosprawnych - postawy i ich determinanty, Annales Academiae Paedagogicae Cracoviensis, Folia 14, "Studia Psychologica", 2003, I, pp. 40-41. 


\section{References}

Buchner C., Sukces w szkole jest możliwy, Jedność, Warszawa 2004.

Dweck C., Nowa psychologia sukcesu, Muza S.A., Warszawa 2013.

Gołąb K., 10 złotych zasad sukcesu, https:/ / posukcesnaszpilkach.pl/2014/10-zlotychzasad-sukcesu/ [10.10.2019].

Karpińska A., W poszukiwaniu źródet edukacyjnego sukcesu. Oferta edukacyjna dla wszystkich, [in:] Edukacja "głębszego poziomu" w dialogu i perspektywie, ed. A. Karpińska, Trans Humana Wydawnictwo Uniwersyteckie, Białystok 2005.

Kossewska J., Społeczeństwo wobec osób niepetnosprawnych - postawy i ich determinanty, Annales Academiae Paedagogicae Cracoviensis, Folia 14, "Studia Psychologi$\mathrm{ca}^{\prime \prime}, 2003$, I.

Lebowitz S., 12 wptywowych osób dzieli się swoimi zaskakującymi definicjami sukcesu, https:// businessinsider.com.pl/rozwoj-osobisty/rownowaga/czym-jest-sukces -definicje-min-gatesa-bransona-obamy/xr37bcy [10.10.2019].

Nęcka E., Inteligencja. Geneza - Struktura - Funkcje, Gdańskie Wydawnictwo Psychologiczne, Gdańsk 2002.

Rybak W., Sukces edukacyjny osób niepetnosprawnych w kontekście warunków uprawiania turyzmu na terenie Bieszczadzkiego Parku Narodowego, https://www.repozy torium.uni.wroc.pl/Content/79784/7.6_Wojciech_Rybak_Sukces_edukacyjny_ osob_niepelnosprawnych_w_kontekscie_warunkow_uprawiania_turyzmu_na_ terenie_Bieszczadzkiego_Parku_Narodowego.pdf [15.02.2020].

Schawbel D., Arianna Huffington: Why Entrepreneurs Should Embrace The Third Metric, https://www.forbes.com/sites/danschawbel/2014/03/25/arianna-huffington/ \#3a102df11aa4 [10.10.2019].

Stownik języka polskiego, ed. E. Sobol, Wydawnictwo Naukowe PWN, Warszawa 2005.

Tomaszewski T., Główne idee wspótczesnej psychologii, Wydawnictwo Akademickie Żak, Warszawa 1998.

Uczniowski Klub Sportowy, http://www.sosw.poznan.pl/ [01.08.2017].

Wasielewska M., Karpińska A., Hurysz M., Krótka historia Specjalnego Ośrodka Szkolno-Wychowawczego dla Dzieci i Młodzieży Niepetnosprawnej im. Zbigniewa Tylewicza w Poznaniu, CLiWR Demostenes, Poznań 2019.

Witkowski S., Psychologia sukcesu, Wydawnictwo Naukowe PWN, Warszawa 1994. 